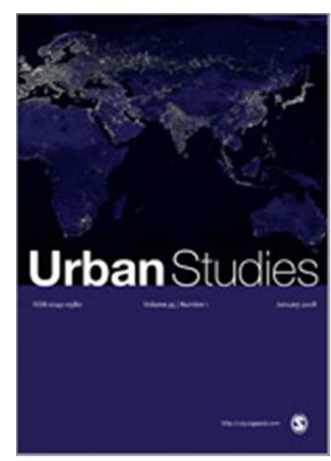

\title{
Supply driven mortgage choice
}

\begin{tabular}{|c|c|}
\hline Journal: & Urban Studies \\
\hline Manuscript ID & CUS-421-15-05.R1 \\
\hline Manuscript Type: & Article \\
\hline $\begin{array}{r}<\mathrm{b}>\text { Discipline: Please select a } \\
\text { keyword from the following list } \\
\text { that best describes the } \\
\text { discipline used in your paper.: }\end{array}$ & Economics \\
\hline $\begin{array}{l}\text { World Region: Please select } \\
\text { the region(s) that best reflect } \\
\text { the focus of your paper. } \\
\text { Names of individual countries, } \\
\text { cities \& economic groupings } \\
\text { should appear in the title } \\
\text { where appropriate.: }\end{array}$ & Europe, Western Europe \\
\hline $\begin{array}{l}\text { Major Topic: Please identify up } \\
\text { to two topics that best identify } \\
\text { the subject of your article.: }\end{array}$ & Housing \\
\hline $\begin{array}{r}\text { Please supply a further } 5 \\
\text { relevant keywords in the fields } \\
\text { below: : }\end{array}$ & Mortgages, Securitisation, Fractional Polynomials, Lending, Margins \\
\hline
\end{tabular}

\section{SCHOLARONE ${ }^{\text {M }}$ \\ Manuscripts}


Abstract: .Variable mortgage contracts dominate the UK mortgage market (Miles, 2004). The dominance of the variable rate mortgage contracts has important consequences for the transmission mechanism of monetary policy decisions and systemic risks (Khandani et al., 2012; Fuster and Vickery, 2013). This raises an obvious concern that a mortgage market such as that in the UK, where the major proportion of mortgage debt is either at a variable or fixed for less than two years rate (Badarinza, et al., 2013; CML, 2012), is vulnerable to alterations in the interest rate regime. Theoretically, mortgage choice is determined by demand and supply factors. So far, most of the existing literature has focused on the demand side perspective, and what is limited is consideration of supply side factors in empirical investigation on mortgage choice decisions. This paper uniquely explores whether supply side factors may partially explain observed/ex-post mortgage type decisions. Empirical results detect that lenders' profit motives and mortgage funding/pricing issues may have assisted in preferences toward variable rate contracts. Securitisation is found to positively impact upon gross mortgage lending volumes while negatively impacting upon the share of variable lending flows. This shows that an increase in securitisation not only improves liquidity in the supply of mortgage funds, but also has the potential to shift mortgage choices toward fixed mortgage debt. The policy implications may involve a number of measures, including reconsideration of the capital requirements for the fixed, as opposed to the variable rate mortgage debt, growing securitisation and optimisation of the mortgage pricing policies.

Keywords: Mortgages *, Securitisation *, Fractional Polynomials *, Lending ", Margins *

\section{Introduction}

The dominance of variable rate mortgage debt in the United Kingdom remains a key characteristic of the UK economy, a possible driver of aggregate economic activity and a puzzle (Leece, 2004). Researchers have evaluated the advantages and disadvantages of fixed-rate mortgage loans, and broadly concur that preferences for variable (adjustable) rate contracts have important consequences for the transmission mechanism of monetary policy decisions and systemic risks (Khandani et al., 2012; Campbell, 2013; Fuster and Vickery, 2013). This raises an obvious concern that such an economy as that in the UK, where the residential mortgage debt to GDP ratio is 83.7\% (EMF, 2011), and where $80 \%$ of that debt is held at variable or fixed for short term rates (CML, 2012), is highly vulnerable to alterations monetary policy decisions. Attaining an understanding of the main reasons behind the prevalence of variable (adjustable) mortgage contracts is therefore of substantial interest to government bodies and mortgage industry investors.

Theoretically, mortgage choice is determined by the demand and supply side factors. From the demand side, the selection of a specific mortgage contract principally depends on income, house price dynamics and the flexibility of tmortgage contract terms (Campbell and Cocco, 2003; Piskorsky and Thistyi, 2011). Additionally, it may depend on personal and demographic characteristics (Sa-Aadu, and Sirmans, 1995; Ling and McGill, 1998), risk preferences (Brueckner, 1994; 1995; Campbell and Cocco, 2003), the opportunity cost of owner occupation (Leece, 2004), interest rate expectations (Leece, 2000a; 2001), liquidity constraints and affordability issues (Leece, 2000b; LaCour-Little, 2009; Bramley and Watkins, 2009). From the supply side, mortgage contract choice is influenced by the institutional features and efficiency of the mortgage finance system (Lanot and Leece, 2014; Leece, 2004; Stephens, 2007; Scanlon and Whitehead, 2011), 
mortgage pricing and mortgage funding mechanisms (Stephens and Quilgairs, 2008; Ambrose and LaCour-Little, 2001; Loutskina, 2011; Badarinza, et.al., 2013, Campbell, 2013), profitability factors (Vickery, 2006; Petersen, et.al., 2012; Fuster and Vickery, 2013), and macroeconomic issues (Miles, 2004; 2005; Whitehead2011).

What is limited so far in the existing mortgage market literature is empirical investigation concerning the extent to which mortgage funding/pricing factors may influence mortgage contract choice decisions and whether recent innovations such as securitisation influence mortgage choice decisions.

This paper addresses the question of whether, in addition to the demand driven factors, the prevalence of variable rate mortgage contracts within the UK mortgage market may be partially explained by supply side arguments. To answer these questions, this work incorporates supply side variables and systematic mortgage choice arguments, differing from previous research in two important respects: firstly, for the first time empirical estimations are applied to the share of variable-rate mortgages in the UK (over a period of 2001-2009). This time frame begins with 2001, the first year when information on variable mortgage share became available, covering the UK's variable-rate market share peak, which is also a period when mortgage backed securities were providing significant funds to the mortgage market. This period also captures the development and subsequent downfall of securitisation associated with the mortgage crisis from 2007-2009, the years of the credit crunch in our dataset. Secondly, this paper employs several explanatory arguments, presumably important for mortgage debt suppliers, including differentials between the profit margins for variable versus fixed over similar maturity Libor rates, and the securitisation rate assuming that these supply side factors are likely to impact preferences for variable (adjustable) versus fixed rate mortgage contracts. Innovatively facilitating the practical advantages of the multivariable fractional polynomial regressions (MFPs) which are proposed to powerfully extend generalised linear models, estimations take the form of two reduced form equations that are formulated to analyse ex-post mortgage choice decisions accounting for the supply side perspective. Time series estimations utilise data from several reliable sources, including the Bank of England, Nationwide, European Mortgage Federation, and Council of Mortgage Lenders databases.

The paper is structured as follows. The next section analyses relevant literature while the third section presents the econometric methodology applied in the paper. The fourth section details the empirical specifications and the fifth section describes the data. The sixth section presents the main findings and results. The penultimate section offers discussion, while the final section forms the conclusion.

\section{Literature Review}

This section analyses the key theoretical and empirical approaches adopted in mortgage choice literature. This is with the aim to establish a theoretical context in which to 
position mortgage choice decisions and to inform empirical specifications accounting for the supply side arguments.

The majority of studies on mortgage choice decisions have analysed mortgage demand models that are based upon utility maximisation theory from a life cycle perspective (Brueckner and Follain, 1988; Follain, 1990; Jones, 1993; Brueckner, 1994; Follain and Dunsky, 1997; Ling and McGill, 1998; Campbell and Cocco, 2003). By linking housing and mortgage demand with the choice of the size and type of mortgage debt, these models provide a theoretical basis for mortgage choice decisions from the demand side perspective. Neglecting supply side factors, these works implicitly assumed a perfectly elastic supply curve (Jones and Miller, 1995). It may be possible, however that lenders might affect mortgage choice decisions following asset-liability matching considerations and being constrained by the institutional framework (Lanot and Leece, 2014; Badarinza et. al., 2013).

Prior to the early 1980s, the main source of mortgage finance came from building societies, which operated as an interest rate "cartel" (Stephens, 2007). Under this system, the Building Societies Association Council introduced interest rates to be paid on savings and charged on mortgage contacts, and at this time the majority of building societies complied with these recommendations (Bacon, 2007). Weakened competition and constrained ability of building societies to raise sufficient funds to match the demand for mortgage finance, resulted in periods of negative real interest rates and excessive mortgage demand (Whitehead and Williams, 2011). This was a starting-point for structural and institutional changes, characterised by legislative innovations, which allowed banks to become mortgage lenders (Whitehead and Williams, 2011).

As a consequence, in the late 1980s the building societies lost their monopolistic market share, generating competition in the mortgage market (Stephens, 2007). The immediate outcome of competition was characterised by a fall in interest rates and accessibility of wholesale funds (Stephens and Quilgars, 2008). This has strengthened the competitive position of the banks, enabling centralised lenders to enter the market that started to use securitisation as a source of mortgage funds (Pryke and Whitehead, 1994; Leece, 2004).

Subsequent developments prompted financial flows from capital markets into the mortgage market, determining mortgage rates by market wholesale rates (Miles, 2005). According to Pryke and Whitehead (1994) and Miles (2004), this has been facilitated by increased margins between the Libor (benchmark for wholesale funds) and mortgage rates. This has made mortgage and capital markets more highly interdependent and integrated (Greene and Watcher, 2005). At this point, structural developments appeared to have created an efficient and smoothly operating system, in which competitive forces have created a large variety of mortgage contracts (Diamond and Lea, 1992; Miles, 2004). 
The source of housing finance in the United Kingdom originates from a combination of sources, predominantly from retail deposits, securitisation and wholesale funds (CML, 2012). A fundamental point to consider is that the main sources of available funds rely upon a short-term structure, whereas mortgage lending requires long-term financing (Scanlon and Whitehead, 2011). This may have led to a prevalence of variable rate mortgages, as inelastic supply of fixed for several years funds, along with institutional framework constraints may have shifted lending preferences for variable rate mortgage debt, limiting the range of mortgage choices available (Lanot and Leece, 2014).

Another important point to consider relates to pricing and profitability factors. Becker, et al., (2010) suggest that differences in variable versus fixed over Libor margins determine the basis of mortgage pricing mechanisms. Linking the pricing perspective with lenders' profit motives, Miles (2004) highlights that promoting variable choices, UK lenders introduced discounted (teaser) rates for variable contracts. Conventionally, such discounts were available for two years, after which households were expected to move on to the more expensive standard variable rates (Ambrose and LaCour-Little, 2001; FSA, 2009). This may be another reason for dominance of the variable debt, as lenders may have achieved their profits by both switching from discounted to more expensive standard variable rates and by limiting availability of fixed rate choices (Miles, 2005; Miles and Pillonca, 2007; Vickery, 2006).

Exploring mortgage choice decisions accounting for the supply side perspective, Jones and Miller (1995) considered systematic and macro driven mortgage pricing factors. Estimating the effects of continued integration between mortgage and wholesale rates, their empirical experiments explored the overall term structure for variable (adjusted) mortgage rates. The results suggested that an upward sloping term and interest rate structure attracts lenders to offer variable (adjustable) rates, creating an incentive to promote substantial discounts on variable (adjustable) mortgage choices. In an additional study comparing the US and UK mortgage markets and further focusing on the influence of interest rates on mortgage contract choice, Vickery (2006) compared pricing differentials and variable versus fixed rate premiums. Results suggest that differences in premiums for fixed versus variable rates explain the approximate 80 per cent share for variable rate mortgages in the UK.

Another consideration is that; as various mortgage designs involve distinct financial features, the form of a mortgage contract suggests different risk profiles. Variable mortgages impose a higher risk of interest rate changes, as well as liquidity and matching asset-liability risks. From the supply side perspective, interest rate risk is associated with changes in mortgage values, as a result of variations in the term structure of interest rates. The risk of changes to lenders' net worth position if mortgage assets are not matched by liabilities of a similar duration may be reduced by short-term wholesale funding or depositary schemes (Badarinza, et. al,. 2013; Petersen, 2012). Accounting for differences in variable versus fixed contracts risk profiles (Campbell, 2012) establishes that variable rate mortgage designs reduce interest rate risks because 
the term structure of interest rates is conventionally upward sloping. This suggests that a shortage of fixed rate funding flows may have promoted variable rate contract choices.

Leece (2004) suggests that securitisation may assist to direct lenders preferences for fixed rate contracts. Empirically grounded findings indicate that advancements in securitisation have altered the nature of mortgage funding mechanisms and have increased the liquidity of mortgage credit flows, resulting from the ability to transfer illiquid mortgage loans into liquid securitised notes (Pryke and Whitehead, 1994; Loutskina, 2011). By converting illiquid mortgage loans into liquid securitised tools, securitisation alters the originator's liquidity and credit transformations by sheltering suppliers from liquidity problems (Altubasa, et. al., 2009). Further, by mitigating the effects of liquidity and deposit supply, securitisation facilitates mortgage lending mechanisms by linking housing finance with capital markets funding flows (Hendershott and Van Order, 1989; Loutskina and Strahan, 2009). By weakening the link of the associated costs of traditional sources of funding to the interbank credit supply, mortgage securitisation, by extension, makes mortgage lending activity less sensitive to interest rate risks (Sveiby, 2012; Loutskina and Strahan, 2012; Hoffman and Nitschka, 2012). Further, by facilitating the supply of mortgage funds that are less tied to the deposits and interbank loans, securities combined with liquidity, affect not just the supply of mortgage funds per se, but in particular the availability of fixed rate mortgage contracts (Campbell, 2012; Green and Watcher, 2005; Badarinza, et. al., 2013).

\section{Econometric Methodology}

An econometric model is specifically designed to empirically examine ex-post mortgage choice decisions, accounting for the supply side perspective. Two separate reduced form equations focused upon funding, pricing and macroeconomic perspectives were modelled. In both equations (for gross mortgage lending, and the share of variable-rate lending), modelling identifies time series patterns that are relative to the theoretical considerations associated with the response variable $\left(\mathrm{Y}_{\mathrm{i}}\right)$, and a set of explanatory variables $\left(\mathrm{X}_{\mathrm{i}}\right)$ that are anticipated to be statistically significant when presented in estimated form.

To account for a non-linear relationship between the variables, and given that conventional modelling techniques, such as linearized transformations and exponential decays, may distort the error terms (Greene, 2010; Schmidt et. al., 2013), an alternative modelling technique is employed. That is, multivariable fractional polynomials (MFPs), which combine polynomial and logarithmic functions, covering a much wider set of functional forms; these are proposed to powerfully extend the generalised linear model (Sauerbrei et. al., 2007; Royston and Sauerbrei, 2008). Thus, firstly, by modelling a non- 
linear relationship from time series data, the generalised form of the non-linear regression model is (Greene, 2010):

$Y_{i t}=H\left(X_{i t}, \beta_{i}\right)+\varepsilon_{i t}$

After which, to account for the possibility of exponential curvature relationships between the dependent and explanatory variables (Royston and Sauerbrei, 2003), and with the aim of obtaining plausible transformations of covariates, fractional multivariable polynomials are employed (Sauerbrei, et.al, 2006; Tan, et. al., 2009). This takes the following form:

$Y_{i t}=\beta_{0}+\sum_{i=1}^{m} H\left(X_{i t}^{P_{i}}, \beta_{i}\right)+\varepsilon_{i t}$

Where $(\mathrm{m})$ is an integer, $\left(\mathrm{p}_{\mathrm{i}}\right)$ is a real value vector of powers (with $\left.\mathrm{p}_{1}<\ldots<\mathrm{p}_{\mathrm{m}}\right),\left(\beta_{\mathrm{i}}=\beta_{0}\right.$, $\left.\beta_{1}, \ldots, \beta_{\mathrm{m}}\right)$ are the parameter of estimates, and $\varepsilon_{(\mathrm{it})}$ represents the error term. In this model, the polynomial of degree $(\mathrm{m})$ takes the values of $\left(\mathrm{p}_{\mathrm{i}}=1, \ldots ., \mathrm{m}\right)$, with $\beta_{\mathrm{m}} \neq 0$. This is conditional on the given values of $(m)$ and $\left(p_{i}\right)$, where $H_{m}\left(X(i t), p_{i}\right)$ has the form of a linear predictor, relative to the covariate vector $H\left(X_{(i t)}\right)$ and the parameter vector $\left(\beta_{\mathrm{i}}\right)$. By determining the best values for $(\mathrm{m})$ and of the power vector $\left(\mathrm{p}_{\mathrm{i}}\right)$, and finding the optimum combination of powers and integers, multivariable fractional polynomials simultaneously obtain both consistent estimates and best fits for given data points (Royston and Altman, 1994; Sauerbrei et. al., 2007; Wooldridge, 2009; Greene, 2010).

\section{Estimation Features}

To estimate non-linear relationships the traditional assumption of an underlying linear model structure and its application in non-linear estimation procedures may lead to misspecification and biased estimates (Wooldridge, 2009; Greene, 2010). In order to resolve non-linearity and misspecification problems, multivariable fractional polynomials (MFPs) have been integrated into the regression models to model nonlinear relationships for a fixed set of exponents, simultaneously combining variables (at varying powers determined within the model), transformation and test modification procedures (Royston and Sauerbrei, 2007).

Advantageously, the possibility of non-linear causality in multivariable fractional polynomials (MFPs) is eliminated by modelling spurious interactions between predictive and explanatory factors, and by verifying the interdependence of all the variables involved in the estimation process (Heckman, 2008; Nishiayama, et al., 2010; 
Dergiades, et al., 2013). Using a predictor, which varies randomly and independently from those variables included in econometric estimates, estimation procedures resolve the causality issue (Wooldridge, 2002; Antonakis, et al, 2012). Estimation is conducted using STATA, and backward elimination procedures combine essential checks with an adaptive algorithm that selects the best MFP transformation (powers and functions) for each of the variables included in econometric analysis. The powers commands are used to set up and select multivariable models, comprising several non-linear and interactive associations, by specifying significance levels for the selection procedure based on integers and powers. Using the 95\% significant level values associated with the best FP transformations variables are excluded or transformed during the estimation process (Tan, et al., 2011).

Proposed as extensions to well-established methods of non-linear estimations applicable for time series estimates, MFPs represent a class of time dependent transformations (power restricted to a special set of positive and negative integers and fractions); these involve advantageous characteristics, such as close fitting to data points, statistical approximation of asymptotes and parsimony (Royston and Altman, 1997; Long and Ryoo, 2010).

Importantly, the assumption of homoscedasticity is not conditional with MFPs, as in the case of heteroscedasticity, a transformation of a response variable stabilises the variance and removes the skewness of the distribution (Box and Cox, 1964; Altman, 1993; Stock and Watson, 2003). Model instability and selection bias issues are resolved by the sample size restriction, which allows for no less than 10 observations for each variable included in the model (Royston and Sauerbrei, 2008; Greene, 2010).

Considering the order of the parameter of estimates within the fixed set of power transformations, identification is achieved, both by imposing the restriction condition of $\left(\beta_{\mathrm{m}} \neq 0\right)$, and by offering a constancy of estimates and inter-changeability of order for the set of fractional polynomial functions included in the model (Royston and Sauerbrei, 2008; Ambler and Royston, 2001).

A number of checks also have been performed. Stationarity of data checks have involved transformation of values by changing powers, ensuring that there is no systematic change in variance and that consistency with a stationary generating process has been achieved (Shumway and Stoffer 2006). There are also several test checks that have been made to check for the co-linearity and measure the robustness and consistency of the parameters of estimates. To obtain consistency of error estimates and to check for endogeneity issues, instrumental variables has also been used to compare whether estimated results are not significantly different from those obtained from multivariable fractional polynomial regressions.

\section{Empirical Specification}


Econometric specifications provide the basis for the empirical testing of mortgage choice decisions, accounting for the supply side perspective. This includes a combination of supply and demand factors, which may assist in explaining the preferences for variable mortgage type within the UK's mortgage market. Given the inclusion of funding and pricing perspectives, empirical specifications follow the theoretical considerations presented by Leece (2004), Campbell (2012), Vickery (2006), Fuster and Vickery (2013), Debelle (2004) and Miles (2004; 2012). From macroeconomic and pricing perspectives, it is anticipated that the level of gross mortgage lending, as well as variable mortgage lending shares, may be affected by inflation and interest rates, and distinct supply and demand factors. From a funding perspective, it is anticipated that securitisation affects gross mortgage lending volumes, and may influence mortgage contract choice type decisions. The empirical specifications for gross mortgage lending and the share of variable mortgage lending equations are given by expressions (3) and (4) respectively.

$$
\begin{aligned}
& \text { GML = F (RAHPS, INFL, RIR, RMDGDPR, TRMBSI) } \\
& \text { VMLS = F (NIR, INFL, FRP, DMLVFR, TRMBSI) }
\end{aligned}
$$

Thus, gross mortgage lending (GML) appears as a dependent variable, and the gross mortgage lending equation (3) is a function of the explanatory variables outlined below.

From the macroeconomic perspective, in an environment of uncertain economic conditions, the availability of mortgage finance flows is influenced by the volatility of house prices, inflation, and real interest rates (Campbell, 2013; Whitehead and Williams, 2011). This is because fluctuations in house prices, and changes in the macroeconomic environment, create additional risks, which are associated with imbalances in residential real estate debt (Tzatsaronis and Zhu, 2004). From the funding perspective, mortgage financing depends on the degree of integration between the mortgage market and the flows in the capital markets (Leece, 2004; Green and Watcher, 2005; Fuster and Vickery, 2013).

It is expected that an increase in real average house prices (RAHPS) would positively affect mortgage lending flows. This implies that empirical testing of the relationship between house prices and gross mortgage lending volumes could reflect the responsiveness of mortgage lending conditions to the movement in house prices, and expectations of shifts in housing and mortgage demands (Adelino, 2012; Taltavull de La Paz and White, 2012). In reference to macroeconomic influences, inflation (INFL) and real interest rates (RIR) aim to reflect the impact of volatile inflation and changes in real interest rates on the cost, and thus the volume, of mortgage debt (Miles and Pilonca, 2008; Bazarinza et. al., 2013). Mortgage debt is denominated in nominal terms and since wages and inflation are usually positively correlated, higher inflation could impact on the real burden of servicing mortgage debt. However an inflation term could also 
capture wealth effects and GML would rise if house prices rose meaning that perceived wealth would increase (at least in the presence of money illusion). The residential debt to GDP ratio (RMDGDPR) empirically proxies mortgage lending liquidity constraints that refer to the maturity, size and distribution of mortgage debt (Maclennan, et. al., 2000; Rogers, 2009). In relation to the funding perspective, total residential mortgage backed securities issues (TRMBSI) account for the conversion of mortgages into tradeable and liquid financial instruments, thereby exploring the extent to which securitisation influences gross mortgage lending (Loutskina, 2011; Pryke and Whitehead, 1994).

In a variable mortgage lending equation (4), empirical investigation aims to establish whether the dominance of variable mortgage contract choices within the UK's mortgage market, may be partially explained by pricing/funding factors and macroeconomic arguments. Thus, appearing as a dependent variable on the left hand side of the equation, variable mortgage lending share (VMLS) is a function of the following empirical arguments:

Nominal interest rates (NIR) are suggested, to reflect the theoretical proposition that a historic decline in nominal interest rates lowers mortgage funding costs, generating a decline in nominal mortgage rates (Miles 2004; Campbell, 2013). Because the funding for UK mortgages comes predominantly from retail deposits or short term interest rate swaps, higher short term nominal interest rates may positively impact variable mortgage choice decisions (Lanot and Leece, 2014; Campbell, 2013).

Suggested as a proxy for the prevailing financial conditions, inflation (INFL) aims to establish whether volatile inflation, and thus unstable real mortgage costs, may have impacted upon mortgage choice decisions, and the demand for variable debt (Debelle, 2004; 2011; Campbell, 2013). To account for pricing differences, fixed rate premiums (FRP) have been included aiming to explore whether the prevalence of variable lending trends can be accounted for by premiums on fixed repayments (Jones and Miller, 1993; Miles, 2003; Vickery, 2006). Differences in the margins between the variable-Libor versus fixed-Libor mortgage rates (DMLVFR) aim to reflect whether the cost of funds and profit margins has created dominance in the variable mortgage types (Miles, 2004; Campbell, 2012). To account for possibility of that securitisation may direct preferences toward variable mortgage choices, total residential mortgage backed securities issues (TRMBSI), have been included in econometric estimates. It is expected that securitisation impacts mortgage choice decisions by increasing the availability of various mortgage designs and lowering the cost of fixed rate mortgage rates (Petersen, et.al. 2012, Vickery, 2013).

Thus, empirical specification includes supply side variables considering that the mortgage choice decisions are largely systematic; they correlate with the slope and the level of the term structure of interest rates. Therefore, this specification includes 
important mortgage supply variables involving differences between variable versus fixed over Libor rates and securitisation.

\section{Data}

The data employed in the econometric models have been extracted from a range of reliable sources, including the Bank of England Data Archive, Nationwide house price index data, European Mortgage Federation publications and CML research. The dataset covers the period from 2001 to 2009 and is of quarterly frequency. The time frame has been restricted by the availability of data on variable mortgage lending volumes after 2009; however, this period captures radical changes in the macroeconomic environment, characterised by changes in GDP, inflation and changes in the interest rate regime and the rapid decline in securitisation, all of which hypothetically impacted mortgage lending mechanisms and the supply of mortgage funds. The period also captures the recent period of significant real house price inflation and deflation.

As shown in table 1, moving along the time horizon, the economy deteriorated sharply between 2007 and 2009, after a period of economic growth. During this time inflation was highly volatile, rising steadily from 2007 showing a sharp increase in 2008 before decreasing in 2009. Although the annual average Bank of England base rate (BoE) remained between $4.5-5.5 \%$ during the 2001-08 period, there were substantial rate cuts after 2008, reducing average rates to as low as $0.64 \%$ in 2009 . Between 2001, and the first half of 2007, mortgage lending volumes grew with house prices and the premium for fixed rate mortgages over BoE rates was very small. Corresponding with the interest rate regime (with respect to the cost of fixed versus variable rates), after 2008, the fixed rate premium rose sharply. The housing market and mortgage market slowed down considerably, with house prices and mortgage lending sharply declining during the latter two years. Table 1 provides key information on the variables used in the econometric models. It shows that house prices fell by about $16 \%$ in 2008 , and that mortgage lending volumes fell by as much as 60\% during 2008-2009.

\section{Table1. here}

The outcomes for the mortgage market reflect the cyclical nature of economic conditions and house price inflation. Macroeconomic statistics indicate that negative GDP growth, volatile inflation and fluctuations in house prices are also typically accompanied by a substantial decrease in mortgage lending volumes. In addition, mortgage markets are seen to respond to changes in the macroeconomic environment by shifts in mortgage lending strategies. When referring to the links between wholesale rates, and mortgage pricing opportunities, it appears that a combination of mortgage 
pricing margins and mortgage lending mechanisms might be influencing the type of mortgage contract.

Table 2 provides descriptive statistics for the variables in the econometric analysis. A natural logarithmic transformation for several variables was employed so that covariate transformations achieve better parameter estimates and best fits for data points.

Table 2. here

As stated above, the data sample includes mortgage pricing and mortgage rates differentials to uncover supply driven influences in mortgage lending trends. Mortgage pricing profit margins are presented as the difference between the margins of standard variable-Libor and fixed for two years-Libor mortgage rates. The London interbank offered rates are taken of a similar maturity with corresponding mortgage rates, so that 3-monthly rates are used for variable margin calculations. Fixed rate differentials are calculated as the difference between the fixed for two years and standard variable mortgage rates. Standard variable rates are taken because, despite the fact that lenders may offer two years discounted variable rates, variable contracts then follow changes in discounted over standard rate differentiated costs. Fixed rates are taken for two years, as in the UK fixed options are typically fixed for only two years, corresponding with lenders fixed short term funding costs. In absence of average contractual mortgage rates, the interest rates provided by the Bank of England were analysed in this investigation. The remainder of the rates including Libor were also taken from the Bank of England active database. Inflation figures were taken from the government statistics database and average house prices (applied in real terms) were extracted from Nationwide House Price Index data. Gross mortgage lending volumes and variable mortgage lending shares were collected from data provided by major UK mortgage lenders and the Council of Mortgage Lenders research, deflated by a GDP deflator and presented in real terms. Total residential mortgage backed securities issues were provided by European securitisation forum data, and the residential mortgage debt to GDP ratio has been calculated with data from the Bureau of economic analysis and Eurostat research.

\section{Results and Analysis}

\section{Gross Mortgage Lending}

Table 3 presents the empirical results of the time-series estimations for the gross mortgage lending equation (3). Exploring whether the size of mortgage debt relative to the size of the economy imposes liquidity constraints upon gross mortgage lending volumes, this model also aims to identify whether securitisation may have differing impacts upon gross lending volumes than there would be for the variable share of lending flows. The estimation procedures employ multivariable fractional polynomial 
(MFPs) estimation techniques, which aim to explore the impact of various supply and demand factors on gross mortgage lending volumes.

Table3. here

As was expected, an increase in house prices facilitates an increase in mortgage lending streams. This finding is theoretically consistent a priori, as higher house prices lead to expectations of further price increases, therefore triggering rising demand for housing and thus mortgage debt; impacting both mortgage credit conditions and the volume of the mortgage debt (Whitehead and Williams, 2011).

Next, inflation has a negative and significant effect on gross mortgage lending. Growth in the macro-economy may lead to an increase in inflation rates and policy responses in the form of restrictive monetary policies that would tend to slow the housing market, and reduce demand for mortgage debt (Debelle, 2004). Estimation coefficients for real interest rates have a negative impact upon gross mortgage lending flows, suggesting that an increase in real interest rates would increase real mortgage payment costs lowering demand for mortgage debt (Campbell, 2013).

The ratio of residential debt to GDP, used as a proxy for mortgage lending liquidity constraints (Maclennan et al, 2000), negatively affects the gross mortgage lending volume. This may reflect the fact that aggregate household debt exposure (linked to income, size, maturity and distribution of mortgage debt) can restrict mortgage lending volumes.

Finally, to assess the impact of securitisation upon mortgage lending volumes, total residential mortgage backed securities issues were included in the econometric estimates. The results show that securitisation positively impacts on gross mortgage lending volume possibly reflecting the effect of reduction in credit rationing via the minimisation of mortgage funding costs (Leece, 2004).

\section{Variable-Rate Mortgage Lending}

Table 4 represents empirical results of the variable mortgage share equation (4). The estimation procedure analyses ex-post mortgage choices while controlling for the supply side perspective. Empirical estimates involve a combination of mortgage funding, pricing and macro-economic factors.

\section{Table4. here}

Thus, results indicate a positive relationship between nominal interest rates and the share of variable rate mortgages. Under the regime of increasing nominal rates, margins for the variable over Libor versus fixed over Libor for similar maturity rates allowed for 
the higher profits for variable rate lending. A supply side explanation could be that positive coefficients of nominal interest rates on the variable share lending equation, may have reflected lending profit motives which positively influence preferences for variable mortgage debt. Inflation has a negative impact on the share of variable rate mortgages. A demand side explanation could be that in an environment of high inflation rates, borrowers may prefer the certainty of fixed rate products.

The coefficient on the fixed rate premium in the variable share equation is negative, suggesting that with higher fixed rate premiums, borrowers are more likely to choose fixed rate mortgages, and less likely to choose variable mortgage debt. This may reflect preferences to fix mortgage payments as a result of expectations of future increases in interest rates.

Further, we test whether differences in the margins between the variable-Libor and fixed-Libor rates might influence mortgage choice decisions. The positive coefficient for this variable suggests that higher variable-rate profit margins, when linked with similar maturity wholesale rates, may have also contributed to the dominance of variable-rate mortgage contract choices.

Finally, in order to investigate the effect of securitisation on mortgage choice decisions, total backed securitisation issues have been included in the econometric estimates. Empirical findings suggest that securitisation negatively influences the demand for variable mortgage debt, possibly reflecting the effect of lowering the costs of raising funds, cheaper rates for fixed rate mortgage loans and better accessibility of fixed rate choices (Leece, 2004; Vickery, 2006).

For both equations, to check for the consistency of error estimates we apply instrumental variables (IV) estimation techniques. The IV results, also reported in tables 3 and 4 above are the same in sign and similar in magnitude to the MFP results. However, the absolute sizes of estimated coefficients obtained from MFP-s indicate a stronger explanatory power, advocating better consistency and a greater robustness of empirical results for the MFP regressions. Equations have been identified by the supply side variables. Test for the simultaneity in mortgage lending volume and share of variable lending equations did not show appropriate explanatory power and statistically significant results (with p values of 0.269 and 0.748 respectively).

\section{Discussion}

Interest rate shocks have varying impacts on fixed and variable rate mortgage holders. Mortgage payments for fixed rates remain unchanged in light of any increase in interest rates. On the contrary, variable rate mortgage holders are more exposed to financial shocks as mortgage payments are directly affected when interest rates increase. In the UK, where the vast majority of the households hold variable rate mortgage contracts, and where the size of residential mortgage debt is high relative to the absolute size of the economy, changes in monetary policy decisions have the potential to undermine 
national financial stability. This is particularly relevant in the light of the recent debates on proposing changes to the monetary policy regime, meriting concerns of the disproportional impact of changes in interest rates on variable versus fixed mortgage holders. Given that such a disproportional impact may be facilitated by the possibility of lending incentives toward the variable (adjustable) options, detection of what supply side factors may influence households mortgage choice decisions requires significant and timely attention.

This paper suggests that in addition to macroeconomic factors, lenders' profitability motives, pricing structure and shortage in supply of fixed rate funds may have assisted in the prevalently variable rate mortgage choice environment. These findings are very important, as they call for action showing that the UK's households may be faced with greater payment shocks by lending strategies and influences.

The mortgage finance industry is interested in making profitable lending. The policies suggested here do not seek to reduce profitability, but rather consider how to promote fixed rate products that have benefit for macroeconomic stability. Policy implications from the research findings may involve a number of measures including facilitation of fixed rate mortgage offers for liquidity constrained households, allowing for higher loan to value ratios for fixed rate mortgage contract designs. Diminishment of lenders' incentives towards variable mortgage contracts by introduction of more strict capital requirements for variable, as opposed to fixed rate mortgage loans, may be subject to the financial regulatory framework. Growing securitisation and optimisation of the mortgage pricing policies may also be an option.

\section{Conclusion}

The primary aim of this paper has been to address the question of whether dominance of the variable mortgage choices within the UK' mortgage market may have been influenced by the supply side factors. This is an important question as the high level of variable debt is perceived to be a source of economic and mortgage market instability. To answer this question, two reduced form equations have been estimated using UK time-series data for the period 2001-2009. For the first time, the share for variable rate lending has been included in empirical estimates aiming to analyse whether ex-post mortgage choices may be explained by considering the supply side perspective.

The main contribution of this paper is the provision of empirical evidence that larger profit margins for variable-Libor versus fixed-Libor over similar maturity wholesale rates positively influence demand for variable rate mortgage debt. In part this may suggest that lenders profit motives and mortgage funding-mortgage pricing issues may have resulted in preferences toward variable rate contracts. Another finding shows that price differentials between fixed versus variable mortgage rates decrease the share of 
variable rate mortgage choices. This may reflect expectations of future changes in interest rates and borrowers' beliefs that mortgage rates are mean reverting.

Securitisation is found to positively impact upon gross mortgage lending volumes while negatively impacting upon variable lending flows. This is an important finding showing that an increase in securitisation not only increases liquidity in the supply of mortgage funds per se but also has the potential to shift mortgage choices toward fixed rate mortgage debt.

Policymakers may wish, therefore, to consider the potentially beneficial role that can be played by securitisation as a source of adding balance to the operation of the mortgage market. Policy measures may also include support of the fixed rate contracts and review of financial regulation processes.

Acknowledgements: The authors would like to express their gratitude to Professor David Leece for his helpful comments and suggestions on earlier drafts of this paper; and they also thank the anonymous referees for their contribution. Gratitude is also due to professor Patrick Royston and Dr James Vickery for their assistance at the earlier stages of this research. The authors also would like to thank professor Marjan Sarshar for encouragement and support while conducting this research. 


\section{References}

Acharya, V., Schnabl, P. and Suarez, G. (2013) Securitisation without Risk Transfer, Journal of Financial Economics, 107(3), 515-536.

Adelino, M., Schoar, A. and Severino, F. (2012) Credit Supply and House Prices: Evidence from Mortgage Market Segmentation, NBER Working Paper 17832, http://www.nber.org/papers/w17832

Alm, J. and Follain, J.R. (1987) Consumer demand for adjustable rate mortgages, Housing Finance Review 6, 11-17.

Ambler, G. and Royston, P. (2001) Fractional Polynomial Model Selection Procedures: Investigation of Type I Error Rate, Journal of Statistical Computations, 69, 89-108.

Ambrose, B. and LaCour-Little, M. (2001) Prepayment Risk in Adjustable Rate Mortgages Subject to Initial Year Discounts: Some New Evidence, Real Estate Economics, 29(2), 305-327.

Antonakis, J., Bendahan, S., Jacquart, P. and Lalive, R. (2012) Causality and Exogeneity: Problems and Solutions. The Oxford Handbook, January, Oxford.

Aron, J. and Muellbauer, J. (2010) Modelling and Forecasting UK Mortgage Arrears and Possessions. CEPR Discussion Paper Number DP7986. Centre for Economic Policy Research (CEPR), London.

Bacon, P. (2007) Tenure Choice, Mortgage Choice, and Lender Behaviour in the Housing Market of England and Wales. PhD Thesis, University of East Anglia, Unpublished Manuscript.

Badarinza, C., Campbell, J. and Ramadorai, T. (2013) What Calls to ARMs? International Evidence on Interest Rates and the Choice of Adjustable Rate Mortgages, scholar.harvard.edu

Bank of England, Credit Conditions Survey (2012)

Box, G. and Cox, D. (1964) An Analysis of Transformations, Journal of the Royal Statistical Society, Series B, 26(2), 211-252.

Bramley, G. and Watkins, D. (2009) Affordability and supply: the rural dimension, Planning Practice and Research 24(2), 185-210.

Brueckner, J.K. (1986) The pricing of interest rate caps and consumer choice in the market for adjustable-rate mortgages, Housing Finance Review 5, 119-136.

Brueckner, J.K. (1994) The demand for mortgage debt: some basic results, Journal of Housing Economics 3, 1-21. 
Brueckner, J.K. and Follain, J.R. (1988) The rise and fall of the ARM: an econometric analysis of mortgage choice, Review of Economics and Statistics 10, 93-102.

Campbell, J.Y. (2013) Mortgage Market Design. Review of Finance 17(1), 1-33.

Campbell, J.Y. and Cocco, J. (2003) Household Risk Management and Optimal Mortgage Choice. Quarterly Journal of Economics 118(4), 1449-1494.

Council of Mortgage Lenders (CML) (2011) Annual Report, CML, Publications.

Czerwonko, A. (2010) Understanding the U.S. residential subprime mortgage market and its relation to the 2007 financial crisis. Columbia University.

Debelle, G. (2004) Household Debt and the Macroeconomy, BIS Quarterly Review.

Dell'Ariccia, G., Igan, D. and Laeven, L. (2012) Credit Booms and Lending Standards: Evidence from the Subprime Mortgage Market. Journal of Money, Credit and Banking, 44(2-3),

Demyanyk, Y. and Van Hemert, O. (2011) Understanding the Subprime Mortgage Crisis, Review of Financial Studies, 24(6), 1848-1880.

Dergiades, T. (2012) Do Investor Sentiment Dynamics Affect Stock Returns? Evidence from the US Economy, Econometric Letters, 116(3), 404-407.

Diamond, D. and Lea, M. (1992) Housing Finance in Developed Countries: an international Comparison of Efficiency. Journal of Housing Research, 3 (1), 1-27.

Duca, J., Muellbauer, J. and Murphy, A. (2010) Housing Markets and the Financial Crisis of 2007-2009: Lessons for the Future, Journal of Financial Stability, 6(4), 203-217.

European Mortgage Federation (EMF) Hypostat (2011) A Review of Europe's Mortgage and Housing Markets.

Follain, J. R. (1990) Mortgage choice, AREUEA Journal 18(2), 125-144.

Follain, J. R. and Dunsky, R. M. (1997) The demand for mortgage debt and the income tax, Journal of Housing Research 8(2),155-200.

Fuster, A. and Vickery, J. (2013) Securitization and the Fixed-Rate Mortgage. Federal Reserve Bank of New York Staff Reports, No. 594.

Greene, W. (2010) Econometric Analysis, Prentice Hall, Upper Saddle River, NJ.

Greene, W. and Wachter, S. (2005) The American Mortgage in Historical and International Context. Journal of Economic Perspectives, Fall.

Hall, I. (2011) The Coalition and the UK Housing Market, Politics, 31(2), 72-81. 
Heckman, J. (2008) Econometric Causality, International Statistical Review, 76(1), 1-27.

Hendershott, P. and Van Order, R. (1989) Integration of Mortgage and Capital Markets and the Accumulation of Residential Capital, Regional Science and Urban Economics, 19, 189-210.

Hoffman, M. and Nitschka, T. (2012) Securitisation of Mortgage Debt, Domestic Lending and International Risk Sharing, Canadian Journal of Economics, 45(1)

Jones, L. (1993) The Demand for Home Mortgage Debt, Journal of Urban Economics, 33, 10-28.

Jones, S., Miller, N. and Riddiough, T. (1995) Residential Mortgage Choice: Does the Supply Side Matter? Journal of Housing Economics, 4, 71-90.

Kleinman, M. and Whitehead, C. (1988) British Housing Since 1979: Has the System Changed? Housing Studies, 3 (1).

Khandani, AE., Lo, A.W. and Merton, R.C. (2012) Systemic Risk and the Refinancing Ratchet Effect. Journal of Financial Economics

Koblyakova, A. Hutchison, N. and Tiwari, P. (2012) Regional Differences in Mortgage Demand and Mortgage Instrument Choice in the UK. Regional Studies, http://dx.doi.org/10.1080/00343404.2012.750426

LaCour-Little, M. (2009) The pricing of mortgages by brokers: an agency problem?, Journal of Real Estate Research 31(2), 235-263.

Lanot, G. and Leece, D. (2010) The Performance of UK Securitized Subprime Mortgage Debt: 'Idiosyncratic' Behaviour or Mortgage Design? http://mpra.ub.unimuenchen.de/27137/

Lanot, G. and Leece, D. (2014) Mortgage Loan Characteristics, Unobserved Heterogeneity and the Performance of United Kingdom Securitised Sub-Prime Loans, Umea Economic Studies, us

Leece, D. (1995) An econometric analysis of the choice of mortgage design in the United Kingdom, Applied Economics 27, 1173-1186.

Leece D. (2000a) Household choice between fixed and floating rate debt: a binomial probit model with correction for classification error, Oxford Bulletin of Economics and Statistics 62, 61-82.

LEECE D. (2000b) Choice of mortgage instrument, liquidity constraints and the demand for housing debt in the United Kingdom. Applied Economics 32, 1121-1132. 
Leece, D. (2001) The impact of mortgage market innovation on housing demand and household gearing in the United Kingdom: a simultaneous equation model. Paper presented at the RICS Cutting Edge Conference, 2001, Oxford Brookes University, Oxford, UK.

Leece, D. (2004) Economics of the Mortgage Market: Perspectives on Household Decision Making. Blackwell, London.

Leece, D. (2006) Testing a theoretical model of mortgage demand on UK data, Applied Economics 38, 2037-2051.

Ling, D. and McGill, G. (1998) Evidence on the demand for mortgage debt by owneroccupiers, Journal of Urban Economics 44, 391-414.

Long, J. and Ryoo, J. (2010) Using Fractional Polynomials to Model Non-Linear Trends in Longitudinal Data, British Journal of Mathematical and Statistical Psychology, 63(1), 177-203

Loutskina, E. (2011) The Role of Securitisation in Bank Liquidity and Funding Management, Journal of Financial Economics, 100, 553-684.

Loutskina, E. and Strahan, P.E. (2009) Securitization and the Declining Impact of Bank Finance on Loan Supply: Evidence from Mortgage Originations. Journal of Finance 64(2) 861-889.

Meen, G. (2011) The economic consequences of mortgage debt. Journal of Housing and the Built Environment, 26, 263-276.

Mian, A. and Sufi, A. (2009) The Consequences of Mortgage Credit Expansion: Evidence from the 2007 Mortgage Crisis, Quarterly Journal of Economics, 124(4), 1449-96.

Miles D. (2003) The UK Mortgage Market: Taking a Longer-Term View - Interim Report. HM Treasury, London, United Kingdom.

Miles, D. (2004) The UK Mortgage Market: Taking a Longer-Term View. Final Report and Recommendations, HM Treasury, United Kingdom.

Miles, D. (2005) Incentives, Information and Efficiency in the UK Mortgage Market, Economic Journal, 115(502), C82-C98.

Miles, D. (2012) Demographics, House Prices and Mortgage Design, Bank of England, Discussion Paper 35.

Miles, D. and Pillonca, V. (2008) Financial Innovation and European Housing and Mortgage Markets, Oxford Review of Economic Policy, 24(1), 145-175.

Petersen, M.A., De Waal, B., Mukuddem-Petersen, J. and Mulaudzi, M.P. (2012) Subprime mortgage funding and liquidity risk, Quantitative Finance, 1-11 
Piskorski T. and Tchistyi A. (2011) Stochastic House Appreciation and Optimal Mortgage Lending. Oxford University Press.

Pryke, M. and Whitehead, C. (1994) An overview of mortgage-backed securitisation in the UK. Housing Studies, 9(1), 75-101.

Royston, P. and Altman, D. (1994) Regression using fractional polynomials of continuous covariates: Parsimonious parametric modelling. Journal of the Royal Statistical Society. Series C (Applied Statistics) 43(3), 429-467.

Royston, P. and Sauerbrei, W. (2008) Multivariable Model Building. A Pragmatic Approach to Regression Analysis Based on Fractional Polynomials for Modelling Continuous Variables. Wiley Series in Probability and Statistics; Wiley, Oxford.

Royston, P. and Sauerbrei, W. (2007) Improving the Robustness of Fractional Polynomial Models by Preliminary Covariates: A Pragmatic Approach, Computational Statistics and Data Analysis, 51(9), 639-659.

Royston, P. and Sauerbrei, W. (2003) Stability of Multivariable Fractional Polynomial Models with Selection of Variables and Transformations: A Bootstrap Investigation, Statistics in Medicine, 22, 639-659.

Sa-Aadu J. and Sirmans C. (1995) Differentiated contracts, heterogeneous borrowers, and the mortgage choice decision, Journal of Monetary Credit and Banking 27, 498-510.

Sauerbrei, W., Royston, P. and Binder, H. (2007) Selection of Important Variables and Determination of Functional Form for Continuous Predictors in Multivariable Model Building, Statistics in Medicine, 26, 5512-5528.

Sauerbrei, W., Meier-Hirmer, C., Benner, A. and Royston, P. (2006) Multivariable Regression Model Building by Using Fractional Polynomials: Description of SAS, STATA, and R Programs

Scanlon, K. and Whitehead, C. (2011) The UK mortgage market: responding to volatility, Journal of Housing and the Built Environment. 26: 277-293.

Shin, H. (2009) Securitisation and Financial Stability, Economic Journal, 119, 309-322.

Schmidt, C., Itterman, T., Schulz, A., Grabe, S. and Baumeister, E. (2013) Linear, Nonlinear or Categorical: How to Treat Complex Associations in Regression Analyses? Polynomial Transformations and Fractional Polynomials, International Journal of Public Health, 58, 157-160.

Söderberg, S. (2013) Universalising Financial Inclusion and Securitisation of Development, Third World Quarterly, 34(4), 593-612.

Stephens, M. (2007) Mortgage Market Deregulation and its Consequences. Housing Studies, 22 (2), 201-220. 
Stephens, M. and Quilgars, D. (2008) Subprime Mortgage Lending in the UK, European Journal of Housing Policy, 8 (2), 197-215.

Stock, J. and Watson, M. (2003) Introduction to Econometrics, Pearson Education, Inc, Chicago.

Shumway, R. and Stoffer, D. (2006) Time Series Analysis and Its Applications, Springer, Second Edition.

Taltavull de La Paz, P. and White, M. (2012) Fundamental drivers of house price change: the role of money, mortgages, and migration in Spain and the United Kingdom. Journal of Property Research, 29(4), 341-367

Tan, N., Ozguven, F. and Ozuetkin, M. (2009) Robust Stability Analysis of Fractional Order Interval Polynomials, ISA Transactions, 48(2), 166-172.

Tan, N., Thomassen, M., Hjelmborg, J., Clemmensen, A., Andersen, K., Petersen, T., McGue, M., Christensen, K. and Kruse, T. (2011) A Growth Curve Model with Fractional Polynomials for Analysing Incomplete Time-Course Data in Macroarray Gene Expression Studies, Advanes in Bioinformatics, doi: 10.1155/2011/261514.

Tsatsaronis, K. and Zhu, H. (2004) What drives housing price dynamics: cross-country evidence. BIS Quarterly Review, 65-78.

Vickery, J. (2006) Interest Rates and Consumer Choice in the Residential Mortgage Market, Federal Reserve Bank of New York

Whitehead, C. and Williams, P. (2011) Causes and Consequences? Exploring the Shape and Direction of the Housing System in the UK Post the Financial Crisis. Housing Studies, 26(7-8), 1157-1169.

Wooldridge J. M. (2009) Introductory Econometrics: A Modern Approach, SouthWestern, Mason, $\mathrm{OH}$.

R.H. Shumway and D.S. Stoffer (2006). Time Series Analysis and Its Applications.

With R Examples. 2nd edition. Springer. 
Table1. Key macroeconomic, housing and mortgage lending statistics

\begin{tabular}{|c|c|c|c|c|c|c|c|c|c|}
\hline & 2001 & 2002 & 2003 & 2004 & 2005 & 2006 & 2007 & 2008 & 2009 \\
\hline Gross mortgage lending(fm) & 160126 & 220737 & 277343 & 291250 & 288280 & 345355 & 362758 & 254022 & 143276 \\
\hline $\begin{array}{l}\text { Gross domestic product (GDP) } \\
\text { growth }\end{array}$ & 2.5 & 2.1 & 2.8 & 2.8 & 2.2 & 2.9 & 2.6 & 0.5 & -4.9 \\
\hline Inflation & 1.23 & 1.26 & 1.37 & 1.34 & 2.05 & 2.33 & 2.32 & 3.61 & 2.18 \\
\hline Annual average BoE rate & 5.12 & 4.0 & 3.69 & 4.39 & 4.65 & 4.64 & 5.51 & 4.68 & 0.64 \\
\hline $\begin{array}{l}\text { Annual average variable } \\
\text { mortgage rate }\end{array}$ & 6.78 & 5.66 & 5.47 & 6.14 & 6.53 & 6.51 & 7.45 & 6.91 & 4.05 \\
\hline $\begin{array}{l}\text { Annual average two-year fixed } \\
\text { mortgage rate }\end{array}$ & 5.50 & 4.96 & 4.37 & 5.19 & 4.82 & 4.95 & 5.85 & 5.88 & 4.25 \\
\hline $\begin{array}{l}\text { Variable rate premium over } \mathrm{BoE} \\
\text { rate }\end{array}$ & 1.66 & 1.66 & 1.78 & 1.75 & 1.88 & 1.87 & 1.87 & 2.23 & 3.41 \\
\hline Fixed rate premium over BoE rate & 0.38 & 0.96 & 0.68 & 0.8 & 0.17 & 0.31 & 0.34 & 1.20 & 3.61 \\
\hline Annual house price changes & 13.8 & 25.3 & 15.6 & 12.7 & 3.0 & 10.5 & 4.8 & -15.9 & 5.60 \\
\hline
\end{tabular}


Table 2. Descriptive statistics

\begin{tabular}{|c|c|c|c|c|c|c|c|c|}
\hline Variables & Mean & Median & St.dev. & Skewness & Kurtosis & Min. & Max. & Obs. \\
\hline Ln Gross mortgage lending & 10.3751 & 10.4579 & 0.3296 & -0.730 & -0.95 & 9.64 & 10.94 & 36 \\
\hline Ln Variable mortgage lending & 4.0418 & 4.0517 & 0.1982 & -0.378 & -0.619 & 3.64 & 4.34 & 36 \\
\hline Res. mortgage debt GDP ratio & 74.6667 & 77.5000 & 4.0519 & -0.352 & -0.867 & 58.00 & 87.6 & 36 \\
\hline Ln Inflation rates & 0.5986 & 0.5681 & 0.4001 & 0.304 & -0.14 & -0.19 & 1.57 & 36 \\
\hline Real interest rates & 1.8358 & 2.3500 & 1.7581 & -1.079 & 0.458 & -2.06 & 5.05 & 36 \\
\hline Nominal interest rates & 3.8078 & 4.0000 & 1.2969 & -1.492 & 1.886 & 0.50 & 5.88 & 36 \\
\hline Ln. Average house prices & 12.0022 & 12.0903 & 0.22051 & -1.028 & -0.127 & 11.50 & 12.25 & 36 \\
\hline Ln. Total mortgage backed sec. & 2.9537 & 2.9927 & 0.6449 & -0.174 & -0.784 & 1.85 & 3.93 & 36 \\
\hline Fixed rate differentials & -1.0833 & -1.2550 & 0.6303 & 0.909 & 0.044 & -1.97 & 0.46 & 36 \\
\hline Dif. margins of var./fixed over Libor & 1.2838 & 1.2937 & 0.4552 & -0.756 & 0.251 & 0.16 & 1.98 & 36 \\
\hline
\end{tabular}


Table3. Gross Mortgage Lending

\begin{tabular}{lllll|}
\hline Variables & \multicolumn{2}{c}{ MFPs } & \multicolumn{2}{c|}{ IV Estimations } \\
& Coefficient & $\boldsymbol{t}$-value & Coefficient & $\boldsymbol{t}$-value \\
Real average house prices & $1.2927^{* * *}$ & 4.33 & $1.0915^{* * *}$ & 3.62 \\
Inflation & $-0.3610^{* * *}$ & -2.66 & $-0.2853^{* * *}$ & -3.32 \\
Real interest rates & $-0.1282^{* * *}$ & -3.87 & $-0.0746^{* * *}$ & -2.31 \\
Residential debt to GDP ratio & $-1.3553^{* * *}$ & -12.47 & $-1.2457^{* * *}$ & -10.47 \\
$\begin{array}{l}\text { Total residential mortgage } \\
\text { backed securities issues }\end{array}$ & $0.9234^{* * *}$ & 7.80 & $0.6558^{* * *}$ & 5.40 \\
Constant & $10.3751^{* * *}$ & 47.38 & $15.6164^{* * *}$ & 4.4907 \\
\hline
\end{tabular}

http://mc.manuscriptcentral.com/cus Ruth.Harkin@glasgow.ac.uk 
Table4. Variable share lending equation

Dependent variable: Variable-rate mortgage lending share

\begin{tabular}{|c|c|c|c|c|}
\hline \multirow[t]{2}{*}{ Variables } & \multicolumn{2}{|c|}{ MFPs } & \multicolumn{2}{|c|}{ IV Estimations } \\
\hline & Coefficient & t-value & Coefficient & t-value \\
\hline Nominal interest rates & $0.2362^{* * *}$ & 7.83 & $0.0865^{* * *}$ & 2.68 \\
\hline Inflation & $-0.1745^{* * *}$ & -5.35 & $-0.0391^{* * *}$ & -2.60 \\
\hline Fixed rate premium & $-0.1789 * * *$ & -4.05 & $-0.0389^{* * *}$ & -3.50 \\
\hline $\begin{array}{l}\text { Dif. in margins of variable- } \\
\text { Libor \& fixed-Libor rates }\end{array}$ & $0.1868^{* * *}$ & 2.19 & $0.5819^{* * *}$ & 2.68 \\
\hline $\begin{array}{l}\text { Total residential mortgage } \\
\text { backed securities issues }\end{array}$ & $-0.7861^{* * *}$ & -3.17 & $-0.0157^{* * *}$ & -3.32 \\
\hline Constant & $4.0713^{* * *}$ & 28.02 & $3.9115^{* * *}$ & 18.90 \\
\hline
\end{tabular}

